\title{
ASSOCIATION BETWEEN A BIOMARKER OF EXPOSURE TO POLYCYCLIC AROMATIC HYDROCARBONS AND SEMEN QUALITY
}

\section{JOANNA JUREWICZ1 ${ }^{1}$, MICHAŁ RADWAN², WOJCIECH SOBALA ${ }^{1}$, SŁAWOMIR BRZEŹNICKI ${ }^{3}$, DANUTA LIGOCKA ${ }^{4}$, PAWEŁ RADWAN ${ }^{2}$, MICHAŁ BOCHENEK ${ }^{5}$, and WOJCIECH HANKE}

${ }^{1}$ Nofer Institute of Occupational Medicine, Łódź, Poland

Department of Environmental Epidemiology

2 "Gameta" Hospital, Rzgów, Poland

Department of Gynecology and Reproduction

${ }^{3}$ Nofer Institute of Occupational Medicine, Lódź, Poland

Department of Chemical Safety

${ }^{4}$ Nofer Institute of Occupational Medicine, Łódź, Poland

Department of Toxicology and Carcinogenesis

${ }^{5}$ National Research Institute of Animal Production, Kraków, Poland

Department of Biotechnology of Animal Reproduction

\begin{abstract}
Objectives: Growing evidence supports the reproductive and developmental toxicity of polycyclic aromatic hydrocarbons (PAHs) from prenatal and postnatal exposure, but the results of epidemiological studies regarding harmful effects of PAHs exposure on male reproductive system still remain limited and inconclusive. The aim of the present study was to investigate the relationship between 1-hydroxypyrene, a biomarker of polycyclic aromatic hydrocarbons exposure and semen quality. Materials and Methods: The study population consisted of 277 men attending an infertility clinic for diagnostic purposes and having normal semen concentration of 20-300 mln/ml or slight oligozoospermia (semen concentration: $15-20 \mathrm{mln} / \mathrm{ml}$ ) (WHO 1999). All the men were healthy and under 45 years of age. All participants were interviewed and provided a semen sample. The interview included questions concerning demographics, socio-economic status, medical history related to past diseases which may have an impact on semen quality, lifestyle factors and occupational information. Concentrations of 1-hydroxypyrene (1-OHP) in the urine samples were analyzed using high performance liquid chromatography (HPLC). Results: A positive association was found between the level of 1-OHP in urine and sperm neck abnormalities as well as the percentage of static sperm cells ( $p=0.001, p=0.018$, respectively). Additionally, exposure to PAHs measured by 1-OHP in urine decreased semen volume and the percentage of motile sperm cells ( $p=0.014, p=0.0001$, respectively). Conclusions: Presented findings indicate that the environmental level of PAHs exposure adversely affects male semen quality. The future large-scale studies should incorporate different biomarkers to generate a more accurate and full assessment of the effects of PAHs exposure on male fertility.
\end{abstract}

Key words: Semen quality, Sperm DNA damage, PAH exposure, 1-OHP level

The study was performed under the project "Epidemiology of reproductive hazards - multicenter study in Poland" supported by National Center for Research and Development in Poland, from grant no. PBZ-MEiN-/8/2//2006; contract no. K140/P01/2007/1.2.1.2 (Manager of the project: Wojciech Hanke, PhD) and the project "Lifestyle factors and semen quality" financed with a grant for statutory activity IMP 10.19/2013 (Manager of the project: Joanna Jurewicz, PhD).

Received: April 22, 2013. Accepted: September 30, 2013.

Corresponding author: J. Jurewicz, Department of Environmental Epidemiology, Nofer Institute of Occupational Medicine, Lódź, Poland (e-mail: joannaj@imp.lodz.pl). 


\section{INTRODUCTION}

Polycyclic aromatic hydrocarbons (PAHs) are released into the environment as a complex mixture of compounds during incomplete combustion of coal, wood, oil, gas, garbage or other organic substances [1]. PAHs constitute a group of toxic, lipophilic, and endocrine-disrupting chemicals that are widely distributed in the environment [2-7]. Pyrene is one of the most extensively produced PAHs in emissions from the combustion of petrol and diesel and the main source of PAHs in urban environments [8]. Urinary 1-OHP, a major metabolite of pyrene, is considered an appropriate surrogate biomarker of total PAHs exposure of human populations [9-11] and is reported to reflect levels of PAHs exposure from different sources such as ambient air, food and indoor air [12-14]. It has been suggested that urinary 1-OHP reflects exposure to PAHs even at low air pollution levels [8], and it is increasingly being used to biomonitor human exposure to air pollution [15].

As the PAHs are toxins widespread in the environment, exposure to those substances rises public health concern regarding the health effects associated with that exposure. PAHs metabolites are associated with an increased risk for developing different types of cancers, including lung cancer, prostate, skin, lymphatic and hematopoietic malignancies [16,17]. Growing evidence supports the reproductive and developmental toxicity of PAHs from prenatal and postnatal PAHs exposure [18-23]. However, the results of epidemiological studies regarding harmful effects of PAHs on male reproductive system are still limited.

One cohort study by Selevan et al. (2000) [24] reports an association between air pollution episodes of elevated PAHs and increased asthenospermia, abnormal morphology, and abnormal chromatin in human sperm. Another study found that the presence of PAH-DNA adducts in sperm is associated with abnormal morphology [25]. Xia et al. 2009 [26] report that exposure to PAHs at environmental levels is associated with an increased risk of male idiopathic infertility. Also a significant association was found among men with higher 1-OHP level and sperm concentration and sperm number per ejaculum [27]. Among coke-oven workers occupationally exposed to polycyclic aromatic hydrocarbons, the increase in the percentage of sperm with abnormal morphology was observed [28]. The aim of the present study was to investigate the association between 1-hydroxypyrene and semen quality (main semen parameters: volume, concentration, motility, CASA (Computer Assisted Sperm Analysis) parameters, sperm morphology as well as DNA damage in sperm).

\section{MATERIALS AND METHODS}

\section{Study population}

The study population initially consisted of 344 men who were attending an infertility clinic for diagnostic purposes and who had normal semen concentration of 20-300 $\mathrm{mln} / \mathrm{ml}$ or slight oligozoospermia (semen concentration: 15-20 mln/ml) (WHO 1999) [29] from the study entitled "Environmental factors and male infertility", which is a part of the project entitled "Epidemiology of reproductive hazards in Poland - a multicentre study in Poland" supported by the National Center for Research and Development in Poland, grant no. PBZ-MEiN-/8/2//2006. Nofer Institute of Occupational Medicine Bioethical Committee Board approved the study (Resolution No 9/2007, 2007 June 4) and a written informed consent was obtained from all the subjects before commencement of the study. Analysis of 1-OHP in urine was performed among 277 men, so the presented data is based on this sample size. The men who participated in the study were healthy and under 45 years of age. All participants were interviewed and provided a semen sample. The interview included questions concerning demographics, socio-economic status, medical history related to past diseases which may have an impact on semen quality, lifestyle factors and occupational information. Additionally, smoking status was verified by measuring the 
cotinine level in saliva in a laboratory in Nofer Institute of Occupational Medicine, Łódź, Poland. The level of saliva cotinine was measured using high performance liquid chromatography coupled with tandem mass spectrometry/ positive electrospray ionisation (LC-ESI+MS/MS) and the isotope dilution method. This procedure has been validated under ISO 17025 criteria and accredited by the Polish Center of Accreditation (Certificate AB215). The men were recognized as smokers if their cotinine level in saliva was higher than $10 \mathrm{ng} / \mathrm{ml}$.

\section{Semen collection and analysis}

Semen samples were produced on site by masturbation and collected into sterile containers. The specific length of abstinence was obtained. Semen quality parameters volume, sperm concentration and motility - were determined according to the guidelines of WHO 1999 (World Health Organization, 1999) [29]. Sperm counts and percentage motility were assessed using the computerassisted semen analysis (CASA) (Hamilton-Thorne Version 10HTM-IVOS) using 2 Chamber Leja slides (Leja, The Netherlands).

The following CASA parameters were assessed:

- VAP - average path velocity, velocity over a calculated smoothed path;

- VSL - straight line velocity, velocity over the straightline distance between the beginning and the end of a sperm track;

- VCL - curvilinear velocity, velocity over the actual sperm track, which includes all deviations of sperm head movements;

- BCF - beat cross frequency, the frequency with which the sperm crosses the smoothed path;

- ALH - amplitude of lateral head displacements, magnitude of lateral displacement of a sperm head about its average spatial trajectory.

Sperm morphology was quantified using strict Kruger criteria [30]. The semen smears were air-dried, fixed and stained according to Papanicolaou [31]. A total of 200 sperm samples were analyzed.

Assessment of the sperm chromatin structure assay (SCSA) was performed using flow cytometry [32]. After partial denaturation of the DNA $(\mathrm{pH}=1.5)$, the samples were stained with metachromatic fluorochrome: acridine orange $(\mathrm{Ex} / \mathrm{Em}=488 / 525$ and $615 \mathrm{~nm})$. Fluorescence in green $(515-530 \mathrm{~nm})$ and red $(>630 \mathrm{~nm})$ bands was measured using a flow cytometer (DAKO Galaxy, Denmark). The fluorescence bands corresponded to the intact double stranded DNA (green fluorescence) and fragmented, single stranded (red fluorescence) sperm DNA. Approximately 15 000-25 000 spermatozoa were acquired for each sample at a flow rate of 400-500 events/s. An artificial parameter alpha-t (alpha-t $=\operatorname{red} /($ green + red $)$ fluorescence), was created for the calculations. Cells with an abnormal chromatin structure (i.e. fragmented DNA) showed a distinct shift of the alpha t parameter value. The DNA Fragmentation Index (DFI) was calculated according to the formula:

$$
\begin{gathered}
\text { DFI }=(\text { cells with shift } \\
\text { of alpha-t parameter/all cells }) \times 100
\end{gathered}
$$

\section{Measurement of 1-hydroksypyren in urine}

A urine sample was collected into a polypropylene cup from each study subject $(\mathrm{N}=277)$ at the time of their visit at the clinic. The urine samples were stored at $-20^{\circ} \mathrm{C}$ until analysis, which was performed at the laboratory at Nofer Institute of Occupational Medicine in Łódź, Poland. The 1-OHP was analyzed using high performance liquid chromatography (HPLC). The analytical procedure used in this study was based on the method described by Jongeneelen e al. 1987 [33].

The urine samples $(10 \mathrm{ml})$ were adjusted to $\mathrm{pH}=5.0$ with $1.0 \mathrm{M} \mathrm{HCl}$, buffered with $5 \mathrm{ml}$ of $0.1 \mathrm{M}$ acetate buffer $(\mathrm{pH}=5.0)$, and incubated for $16 \mathrm{~h}$ with $1500 \mathrm{U}$ $\beta$-glucuronidasearylsulfatase (Sigma-Aldrich) in a shaking bath at $37^{\circ} \mathrm{C}$. 1-OHP was concentrated by solid phase 
extraction on a C-18, $100 \mathrm{mg}$ cartridge (J.T. Baker, USA). Cartridges were conditioned with $5 \mathrm{ml}$ of water and $10 \mathrm{ml}$ of methanol and finally $10 \mathrm{ml}$ of the urine sample was passed through the cartridge. Cartridge was cleaned by $5 \mathrm{ml}$ of water and dried with vacuum. 1-OHP was eluted using $10 \mathrm{ml}$ of methanol. The solvent was evaporated to dryness by heating at $40^{\circ} \mathrm{C}$ under a gentle stream of nitrogen. The residue was dissolved in $1 \mathrm{ml}$ of methanol and transferred via syringe filter (PTFE $0.45 \mu \mathrm{m}$ ) to autosampler vial.

Standards of 1-OHP were prepared by spiking the nonsmokers' urine with methanolic solution of 1-OHP to obtain the final concentrations ranging from 0 to $5.0 \mu \mathrm{g} / \mathrm{l}$. 1-OHP standards in urine were subjected to the analytical procedures designed for the urine samples. Determinations were made using a Waters Alliance liquid chromatograph equipped with quaternary pump, autosampler, degasser, column oven and Waters 2475 fluorimetric detector. Chromatographic analysis was carried out on a Supelcosil LC-18 $(150 \times 3 \mathrm{~mm})$ column which was eluted with a methanol: water $(7: 3)$ mixture at $0.4 \mathrm{ml} / \mathrm{min}$ flow rate. Fluorimetric detector was programmed to operate at 242 and $388 \mathrm{~nm}$ excitation and emission wavelengths, respectively. Response of the detector to the calibration standards was linear in the whole concentration range $(\mathrm{r}=0.998, \mathrm{RSD}=5 \%)$. The sensitivity of the method is estimated to be $0.2 \mu \mathrm{g} / 1$ [34].

\section{Statistical analysis}

Robust multiple linear regression [35] analysis was used to explore the roles of questionnaire variables and 1-OHP metabolite concentration as predictor of semen quality indicators. The 1-OHP concentrations were log transformed before the statistical analysis. In the regression analysis, season of urine collection was analyzed as categorical variable based on the month of semen collection (MaySeptember, October-April). Binary variables were used for past diseases and current smoking status. Age and sexual abstinence were analyzed as continuous variables. Because of positively skewed distributions of volume, total concentration, $\%$ of static sperm, the variables were $\log$ transformed and sperm neck abnormalities were square root transformed. Additionally, the test of the effect modification of 1-OHP by smoking status and season of semen collection was carried out.

We used standard significance level $(0.05)$ for statistical inference. R 2.15.1 statistical program was used to analyze data [36]. The robust regression model was fitted using robust base package [37].

\section{RESULTS}

\section{Study population}

The study population consisted of 277 men who were attending an infertility clinic for diagnostic purposes. The mean age of the men participating in the study was 32 years old. Most of them had secondary (39\%) or higher (38.3\%) education and only about $23 \%$ had vocational education (Table 1). The duration of the couples' infertility lasted from 1 to 2 years $(36.5 \%)$ and from 2-3 years $(35.4 \%)$. Past diseases which may have impact on semen quality were reported by $13.7 \%$ of the participants. Abstinence before the semen analysis was about 3-7 days (77\%) (Table 1). Almost $44 \%$ of men were smokers, basing on the cotinine level in saliva. The mean cotinine level in saliva was $64.4 \mathrm{ng} / \mathrm{ml}$. The season before semen collection (3 months before collection) was mostly October-April $(63.9 \%)$, only in the case of $36.1 \%$ of the study group it was May-September (Table 1).

\section{Semen quality and level of 1-OHP in urine among the study participants}

Semen quality among the study participants fell into the normal range of WHO (1999) [29] semen quality indicators. The mean semen volume amounted to $3.5 \mathrm{ml}$ (range: $1.7-12.3 \mathrm{ml}$ ) and the semen concentration 
Table 1. Characteristics of the study participants

\begin{tabular}{|c|c|}
\hline Variables & Characteristic \\
\hline \multicolumn{2}{|l|}{ Education [n (\%)] } \\
\hline vocational & $63(22.7)$ \\
\hline secondary & $108(39.0)$ \\
\hline higher & $106(38.3)$ \\
\hline \multicolumn{2}{|l|}{ Smoking determined by cotinine level $[\mathrm{n}(\%)]$} \\
\hline no & $154(56.4)$ \\
\hline yes & $119(43.6)$ \\
\hline missing data & $4(1.4)$ \\
\hline \multicolumn{2}{|l|}{ Level of cotinine in saliva $(\mathrm{ng} / \mathrm{ml})$} \\
\hline mean (standard deviation) & $64.4(178.4)$ \\
\hline median (min.-max) & $2.5(0-2089.3)$ \\
\hline \multicolumn{2}{|c|}{ Past diseases, which may have impact on semen quality [n (\%)] } \\
\hline no & $239(86.3)$ \\
\hline yes & $38(13.7)$ \\
\hline \multicolumn{2}{|l|}{ Duration of couples' infertility [n (\%)] } \\
\hline $1-2$ years & $101(36.5)$ \\
\hline $2-3$ years & $98(35.4)$ \\
\hline $3-5$ years & $41(14.8)$ \\
\hline$>5$ years & $37(13.4)$ \\
\hline \multicolumn{2}{|l|}{ Abstinence $[\mathrm{n}(\%)]$} \\
\hline$<3$ days & $28(10.1)$ \\
\hline 3-7 days & $213(76.9)$ \\
\hline$>7$ days & $36(13.0)$ \\
\hline \multicolumn{2}{|l|}{ Age (years) } \\
\hline mean (standard deviation) & $32.0(4.6)$ \\
\hline median (min.-max) & $31.7(22.7-45.2)$ \\
\hline \multicolumn{2}{|l|}{ Season (3 months before semen collection) $[\mathrm{n}(\%)]$} \\
\hline May-September & $100(36.1)$ \\
\hline October-April & $177(63.9)$ \\
\hline
\end{tabular}

was $49.7 \mathrm{mln} / \mathrm{ml}$ (range: $15-360 \mathrm{mln} / \mathrm{ml}$ ). The percentage of motile sperm cells in the study group constituted about $56 \%$ of all the study sample, the percentage of static sperm cells $-25 \%$ and the percentage of atypical sperm accounted for $48 \%$. The mean CASA parameters were as follows: VAP $-52.7 \pm 11.3 \mu \mathrm{m} / \mathrm{s}, \mathrm{VSL}-43.6 \pm 10.6 \mu \mathrm{m} / \mathrm{s}$, $\mathrm{VCL}-78.3 \pm 16.9 \mu \mathrm{m} / \mathrm{s}, \quad$ ALH $-3.6 \pm 0.8 \mu \mathrm{m}$,
BCF $-26.4 \pm 3.8 \mathrm{~Hz}$. In the case of semen morphology, head abnormalities constituted about $30 \%$, neck abnormalities $-15 \%$ and tail abnormalities $-6 \%$ of the whole study sample. The percentage of sperm cells with DNA damage (DFI) was $16 \%$ (Table 2).

1-OHP concentration in a urine sample was chosen as a biomarker of exposure to PAHs. Among the study 
Table 2. Distribution of semen parameters and the level of 1-OHP in urine among the study participants

\begin{tabular}{|c|c|c|c|c|c|c|}
\hline \multirow{2}{*}{ Variables } & \multirow{2}{*}{$\begin{array}{l}\text { Participants } \\
\text { (n) }\end{array}$} & \multicolumn{5}{|c|}{ Statistical variables } \\
\hline & & $\mathrm{M} \pm \mathrm{SD}$ & 25 percentile & 50 percentile & 95 percentile & min.-max \\
\hline 1-OHP $(\mu \mathrm{g} / \mathrm{l})$ & 277 & $0.33 \pm 0.31$ & 0.15 & 0.24 & 0.68 & $0.04-1.95$ \\
\hline 1-OHP/creat $(\mu \mathrm{g} / \mathrm{g}$ creat $)$ & 277 & $0.27 \pm 0.24$ & 0.12 & 0.20 & 0.65 & $0.02-2.03$ \\
\hline DFI $(\%)$ & 222 & $15.84 \pm 10.99$ & 8.34 & 12.77 & 35.66 & $2.72-71.23$ \\
\hline Sperm head abnormalities (\%) & 276 & $29.61 \pm 18.26$ & 15.75 & 25.00 & 90.00 & $0.00-93.00$ \\
\hline Sperm neck abnormalities (\%) & 276 & $14.51 \pm 8.58$ & 8.00 & 12.00 & 29.00 & $0.00-44.00$ \\
\hline Sperm tail abnormalities (\%) & 276 & $6.25 \pm 6.25$ & 2.00 & 5.00 & 15.00 & $0.00-42.00$ \\
\hline Volume (ml) & 276 & $3.46 \pm 1.46$ & 2.50 & 3.00 & 6.00 & $1.70-12.30$ \\
\hline Semen concentration $(\mathrm{mln} / \mathrm{ml})$ & 277 & $49.65 \pm 54.02$ & 20.40 & 29.60 & 153.25 & $15.00-360.00$ \\
\hline Motility (\%) & 273 & $56.07 \pm 20.61$ & 44.00 & 54.00 & 93.10 & $4.00-99.00$ \\
\hline Static sperm $(\%)$ & 272 & $24.78 \pm 18.99$ & 11.00 & 19.00 & 64.15 & $1.00-91.00$ \\
\hline Atypical sperm (\%) & 275 & $48.44 \pm 20.56$ & 32.00 & 45.00 & 94.00 & $11.00-96.00$ \\
\hline $\operatorname{VAP}(\mathrm{um} / \mathrm{s})$ & 274 & $52.70 \pm 11.32$ & 44.85 & 52.65 & 71.21 & $15.10-86.60$ \\
\hline VSL (um/s) & 274 & $43.61 \pm 10.58$ & 37.00 & 42.95 & 61.41 & $14.90-77.10$ \\
\hline VCL (um/s) & 274 & $78.34 \pm 16.90$ & 66.83 & 78.10 & 95.21 & $20.80-146.00$ \\
\hline ALH (um) & 272 & $3.55 \pm 0.76$ & 3.08 & 3.50 & 4.81 & $1.90-6.90$ \\
\hline $\mathrm{BCF}(\mathrm{Hz})$ & 273 & $26.37 \pm 3.81$ & 24.00 & 26.20 & 32.31 & $15.50-37.70$ \\
\hline
\end{tabular}

$\mathrm{M}$ - mean; SD - standards deviation.

1-OHP - 1-hydroxypyrene; DFI - DNA fragmentation index; VAP - velocity average path; VSL - velocity straight line; VCL - velocity curvilinear; $\mathrm{BCF}$ - beat cross frequency; ALH - amplitude of lateral head displacement.

participants the level of 1-OHP in urine was $0.33 \pm 0.31 \mu \mathrm{g} / \mathrm{l}$ (range: $0.04-1.95 \mu \mathrm{g} / \mathrm{l}$ ). When the level of 1-OHP in urine was adjusted for creatinine the mean was $0.27 \mu \mathrm{g} / \mathrm{g}$ of creatinine and the range: $0.02-2.03 \mu \mathrm{g} / \mathrm{g}$ of creatinine (Table 2).

\section{Association between the level of 1-OHP in urine and semen quality}

A positive association was observed between the level of 1-OHP in urine and sperm neck abnormalities $(p=0.002)$ and a negative one between the semen volume $(p=0.015)$ and the percentage of motile sperm cells $(p=0.0001)$ (Table 3). Also in the adjusted analysis a positive association was found between the level of 1-OHP in urine and sperm neck abnormalities and the percentage of static sperm cells ( $p=0.001, p=0.018$, respectively). Additionally, exposure to PAHs measured by 1-OHP in urine decreased the semen volume and the percentage of motile sperm cells $(p=0.014$, $\mathrm{p}=0.0001$, respectively). The model was adjusted for age, smoking, past diseases which may have impact on semen quality (e.g. mumps, cryptorchidism, testes surgery, testes trauma), season of the year (May-September, OctoberApril) and sexual abstinence (Table 3).

The association between 1-OHP and sperm neck abnormalities and the percentage of motile sperm cells was stronger among the smokers subgroup (coef $=3.10$; $\mathrm{p}=0.001$ and coef $=-9.15 ; \mathrm{p}<0.0001$, respectively) and when the semen was collected in October-April season ( coef $=2.53 ; \mathrm{p}=0.001$ and coef $=-7.60 ; \mathrm{p}<0.0001$, respectively) (Table 3). No differences between exposure to 1-OHP and the semen volume and the percentage of static sperm cells in the subgroup of smokers and men 
Table 3. Association between the level of 1-OHP in urine and the semen parameters - the univariate and multivariate models

\begin{tabular}{lrrrrrr}
\hline & \multicolumn{7}{c}{ 1-OHP/creatinine $(\mu \mathrm{g} / \mathrm{g}$ creat $)$} \\
\cline { 2 - 6 } \multicolumn{1}{c}{ Variables } & \multicolumn{7}{c}{ crude } & \multicolumn{3}{c}{ adjusted } \\
\cline { 2 - 6 } & coef & $95 \%$ CI & $\mathrm{p}$ & coef & $95 \%$ CI & $\mathrm{p}$ \\
\hline DFI (\%) & -0.04 & $-0.16-0.07$ & 0.477 & -0.04 & $-0.16-0.08$ & 0.521 \\
Sperm head abnormalities (\%) & 0.02 & $-2.84-2.88$ & 0.987 & 0.61 & $-2.34-3.55$ & 0.687 \\
Sperm neck abnormalities (\%)* & 1.97 & $0.71-3.23$ & $\mathbf{0 . 0 0 2}$ & 2.12 & $0.84-3.40$ & $\mathbf{0 . 0 0 1}$ \\
Sperm tail abnormalities (\%) & 0.11 & $-0.51-0.74$ & 0.723 & -0.01 & $-0.19-0.16$ & 0.895 \\
Volume (ml) & -0.17 & $-0.03-0.31$ & $\mathbf{0 . 0 1 5}$ & -0.06 & $-0.01-0.11$ & $\mathbf{0 . 0 1 4}$ \\
Semen concentration (mln/ml) & 3.99 & $-1.99-9.97$ & 0.192 & 0.09 & $-0.11-0.28$ & 0.385 \\
Motility (\%) & -7.86 & $-4.61-11.11$ & $\mathbf{0 . 0 0 0 1}$ & -8.33 & $-5.07-11.60$ & $\mathbf{0 . 0 0 0 1}$ \\
Static (\%) & 2.14 & $0.36-4.64$ & 0.095 & 0.16 & $0.03-0.29$ & $\mathbf{0 . 0 1 8}$ \\
Atypical (\%) & -0.08 & $-3.47-3.32$ & 0.964 & 0.38 & $-3.12-3.88$ & 0.832 \\
VAP (um/s) & 0.33 & $-1.48-2.14$ & 0.720 & 0.88 & $-0.94-2.71$ & 0.344 \\
VSL (um/s) & 0.10 & $-1.60-1.80$ & 0.909 & 0.71 & $-1.01-2.42$ & 0.419 \\
VCL (um/s) & 0.59 & $-1.99-3.17$ & 0.654 & 0.98 & $-1.64-3.61$ & 0.463 \\
ALH (um) & 0.07 & $-0.05-0.18$ & 0.251 & 0.06 & $-0.06-0.18$ & 0.350 \\
BCF (Hz) & -0.26 & $-0.88-0.35$ & 0.402 & -0.05 & $-0.67-0.56$ & 0.868 \\
\hline
\end{tabular}

Adjusted for age, smoking (cotinine > $10 \mathrm{ng} / \mathrm{ml}$ ), past diseases, season of year (May-September, October-April), sexual abstinence.

$\mathrm{CI}$ - confidence interval.

* The association between 1-OHP and sperm neck abnormalities was stronger in among smokers subgroup (coef $=3.10 ; p=0.001$ ) and when the semen was collected in October-April season ( $\operatorname{coef}=2.53 ; \mathrm{p}=0.001)$.

** The association between 1-OHP and percentage of motile sperm cell was stronger in among smokers subgroup $($ coef $=-9.15 ; \mathrm{p}<0.0001)$ and when the semen was collected in October-April season ( $\operatorname{coef}=-7.60 ; p<0.0001)$.

Other abbreviations as in Table 2.

Bold fonts - statistically significant variables.

whose semen was collected in October-April season were observed.

\section{DISCUSSION}

In the present study, exposure to PAHs measured by 1-OHP level in urine was significantly positively associated with sperm neck abnormalities and the percentage of static sperm cells. Additionally, 1-OHP level in urine decreased the semen volume and the percentage of motile sperm cells when adjusted for potential confounders.

Little epidemiologic data is available on the effects of PAHs on male reproductive function. Human studies among patients from infertility clinics show that subjects with higher urinary concentrations of 1-OHP, 2-hydroxyfluorene (2-OHF) and a sum of PAHs metabolites (assessed as tertiles) are more likely to have idiopathic male infertility (p-value for trend $0.034,0.022$ and 0.022 , respectively). Higher idiopathic infertility risk was found in the group of idiopathic infertile subjects with the abnormal semen quality [26].

In the next study by the same authors i.e. Xia et al. (2009), it was found that the men with higher 1-OHP (assessed as quintiles) are more likely to have below-reference sperm concentration and sperm number per ejaculum [27]. Another study found that the presence of PAH-DNA adducts in sperm is associated with abnormal morphology [25]. PAH-DNA adducts were negatively correlated with the 
percentage of physiologic forms $(\mathrm{p}=0.016)$ and with abnormalities of the neck of the sperm cells ( $p \geq 0.009$ ), while they were positively correlated with morphological abnormalities of the head ( $p>0.0001$ ). PAH-DNA adducts levels were significantly higher in the infertile versus fertile men $(p=0.04)$ [25]. The studies in general populations indicate that the environmental level of PAHs exposure is associated with the increased sperm DNA damage but not with the semen parameters or morphology [1]. Another study in general population by Rubes et al. (2005) reports that PAHs exposure does not change semen quality [38]. One cohort study from Selevan et al. (2000), [24] reports an association between air pollution episodes of elevated PAHs and the increased asthenospermia, abnormal morphology, and abnormal chromatin in human sperm. In the study by Hsu et al. (2006) [28] among coke-oven workers from a steel plant in southern Taiwan occupationally exposed to high levels of PAHs, the number of workers with oligospermia and the percentage of abnormal sperm morphology was significantly greater in topside oven workers than in the side-oven workers. [28]. The later two studies performed among the same group of Taiwanese workers found that urinary 1-OHP does not significantly correlate with semen quality; however, PAHs with heavy molecular weight, e.g., benzo(g,h,i)perylene and benzo(k)fluoranthene, negatively correlate with morphology and motility of sperm cells $(\mathrm{p}=0.02$ and 0.002 , $p=0.04$ and 0.04 , respectively) [39]. The second study by Jeng et al. (2013) did not find any significant differences in sperm concentrations, vitality and DNA fragmentation between the topside oven workers (exposed) and the side oven workers (unexposed) [40].

Our finding is in agreement with those of Sram et al. (1999) [41] and Selevan et al. (2000) [24] where young men from the Czech Republic exposed to PAHs-polluted air had poor semen quality, measured as the increase in abnormal morphology, abnormal chromatin, and asthenospermia. The inconsistency in the results may be explained by the variations in the PAHs background level and/or by the fact that the studies were based on general or infertile populations.

We were not able to examine a representative sample of general male population. Therefore, we tried to overcome this disadvantage by selecting out of infertility male patients only the men with normal semen parameters or with slight oligozoospermia according to WHO classification (1999) [29]. 1-hydroxypyrene (1-OHP) was first identified as a major metabolite of pyrene [42], accounting for about $90 \%$ of the total urinary excretion of pyrene basing on the data from the study using experimental animals. Urinary 1-OHP is considered an appropriate surrogate biomarker of total PAHs exposure of human populations $[3,10,11]$ and it is increasingly used as a biomarker of human exposure to air pollution [15]. 1-OHP levels, after environmental exposures, are lower by one to two orders of the magnitude as compared to occupational exposure depending on background exposures and smoking habits [44].

Although 1-OHP is the most commonly used indicator of PAHs exposure in many previously reported studies, some studies suggest that it may not represent the numerous PAHs metabolites [22]. However, in the study by Hsu et al. (2006) [28] assessing the sperm damage after exposure to polycyclic aromatic hydrocarbons the authors noticed that 1-OHP can be used as a biomarker predicting sperm dysfunction [28].

Most of the studies which examine the association between exposure to PAHs and sperm quality indicate that 1-OHP may affect male semen quality even at non-occupational exposure levels $[24,25,27,41]$. Also animal studies [44,45] indicate such association. Commission of the German Federal Environment Agency established 1-OHP levels in urine of $0.5 \mu \mathrm{g} / \mathrm{l}$ as the reference value for non-smoking general population aged between 3-69 years [47]. The reference value is defined to be the 95th percentile of the values measured for the substance concentration in the 
relevant body medium of the respective reference population. In our study the 95th percentile of the urinary concentration of 1-OHP was higher $-0.68 \mu \mathrm{g} / \mathrm{l}$. This can be explained by the fact that some of our study subjects were smokers and in Poland solid fuels such as coal are used to a much greater extent than in Germany.

A number of biological mechanisms are proposed to contribute to the association we observed between PAHs exposure and poorer semen quality, but the exact mechanism of PAHs toxicity still remains unknown [20]. PAHs and their metabolites may be hormonally active $[48,49]$. PAHs can bind and stimulate the acryl hydrocarbon receptor (AhR) which, in turn, may induce increased metabolism of PAHs to biologically active products that can interact with DNA and promote cancer, or other adverse outcomes [50]. As regards the male reproductive system, human sperm expresses abundant amounts of AhR and aryl hydrocarbon receptor nuclear translocator mRNA, and the presence of AhR in sperm provides a mechanism by which environmental PAHs, dioxins and polyhalogenated biphenyls could directly influence sperm function [51]. Smoking is reported as a risk factor for male reproductive function and may confound the analyses for the associations between environmental pollution and sperm quality [52]. In our study, after adjusting for smoking status, the level of 1-OHP in urine was significantly positively associated with sperm neck abnormalities, the percentage of motile sperm cells and negatively with the percentage of static sperm and semen volume. We observed the association between 1-OHP and sperm neck abnormalities, percentage of motile sperm cells which was stronger in the smokers subgroup (smoking status was determined using the cotinine level in saliva).

In the present study the results were adjusted for the season of semen collection (3 months before collection, which indicates the time of semen production) - the predictor of house heating as the houses are mostly heated in the winter and autumn season. The association between 1-HP and sperm neck abnormalities, percentage of motile sperm cells was stronger in the men whose semen was collected in October-April season.

Using only a single urine sample to predict metabolite concentrations over longer periods [53] may be a potential limitation of our study, but as far as we are aware, all the study participants had not changed their life styles or environments for several months prior to sample collection so their PAHs exposure may be relatively stable over time.

Our study has also several strengths. The results were adjusted for many factors that may be associated with semen quality. Additionally, the smoking status was verified using the level of cotinine in saliva. A third strength arises from the fact that many different semen parameters were included in the analysis: main semen parameters i.e.: volume, concentration, motility, CASA parameters, morphology and sperm chromatin structure.

In conclusion, the presented findings indicate that the environmental level of PAHs exposure adversely affects male semen quality. The future large-scale studies should incorporate different biomarkers to generate a more accurate and full assessment of the effect of PAHs exposure on male fertility.

\section{REFERENCES}

1. Han X, Zhou N, Ciu Z, Ma M, Li L, Cia M, et al. Association between urinary polycyclic aromatic hydrocarbon metabolites and sperm DNA damage: A population study in Chongqing, China. Environ Health Perspect. 2011;119(5):652-7, http:// dx.doi.org/10.1289/ehp.1002340.

2. Santodonato J. Review of the estrogenic and antiestro-genic activity of polycyclic aromatic hydrocarbons-relationship to carcinogenicity. Chemosphere. 1997;34:835-48.

3. Agency for Toxic Substances and Disease Registry (ATSDR), Mumatz M, George J. Chemical and physical information. In: ATSDR, Mumatz M, George J. Toxicological profile for 
polycyclic aromatic hydrocarbons (PAHs). Atlanta: ATSDR; 1995 [cited 2013 March 15], pp. 209-21. Available from: http://www.atsdr.cdc.gov/toxprofiles/tp69-c3.pdf.

4. Ramesh A, Archibong AE, Hood DB, Guo Z, Loganathan BG. Global Environmental distribution and human health effects of polycyclic aromatic hydrocarbons. In: Loganathan BG, Lam PKS, editors. Global contamination trends of persistent organic chemicals. Boca Raton: CRC Press; 2011. p. 95-124.

5. Piskorska-Pliszczynska J, Keys B, Safe S, Newman MS. The cytosolic receptor binding affinities and AHH induction potencies of 29 polynuclear aromatic hydrocarbons. Toxicol Lett. 1986;34(1):67-74.

6. Clemons JH, Allan LM, Marvin CH, Wu Z, Mccarry BE, Bryant DW, et al. Evidence of estrogen-like and TCDDlike activities in crude and fractionated extracts of PM10 air particulate material using in-vitro gene-expression assays. Environ Sci Technol. 1998;32(12):1853-60, http://dx.doi. org/10.1021/es971124n.

7. Tran DQ, Ide CF, McLachlan JA, Arnold SF. The anti-estrogenic activity of selected polynuclear aromatic hydrocarbons in yeast expressing human estrogen receptor. Biochem Biophys Res Commun. 1996 Dec 4;229(1):101-8.

8. Castaño-Vinyals G, D’Errico A, Malats N, Kogevinas M. Biomarkers of exposure to polycyclic aromatic hydrocarbons from environmental air pollution. Occup Environ Med. 2004;61:e12, http://dx.doi.org/10.1136\%2Foem.2003.008375.

9. Levin JO. First international workshop on hydroxypyrene as a biomarker for PAH exposure in man - summary and conclusions. Sci Total Environ. 1995;163:164-8, http://dx.doi. org/10.1136/oem.2003.008375.

10. Jongeneelen FJ. Methods for routine biological monitoring of carcinogenic PAH-mixtures. Sci Total Environ. 1997;199:141-9.

11. Siwinska E, Mielzynska D, Smolik E, Bubak A, Kwapulinski J. Evaluation of intra and interindividual variation of urinary 1-hydroxypyrene, a biomarker to polycyclic aromatic hydrocarbons. Sci Total Environ. 1998;217:175-83.
12. Gilbert NL, Viau C. Biological monitoring of environmental exposure to PAH in the vicinity of a Soderberg aluminium reduction plant. Occup Environ Med. 1997;54:619-21.

13. Vyskocil A, Fiala Z, Fialova D, Krajak V, Viau C. Environmental exposure to polycyclic aromatic hydrocarbons in Czech Republic. Hum Exp Toxicol. 1997;16:589-95.

14. Vyskocil A, Fiala Z, Chenier W, Krajak L, Ettlerova E, Bukac J. Assessment of multipathway exposure of small children to PAH. Environ Toxicol Pharmacol. 2000;8:111-8, http://dx.doi.org/10.1016/S1382-6689(00)00032-6.

15. Hansen AM, Mathiesen L, Pedersen M, Knudsen LE. Urinary 1-hydroxypyrene (1-HP) in environmental and occupational studies - A review. Int J Hyg Environ Health. 2008;211:471503, http://dx.doi.org/10.1016/j.ijheh.2007.09.012.

16. Armstrong B, Hutchinson E, Unwin J, Fletcher T. Lung cancer risk after exposure to polycyclic aromatic hydrocarbons: A review and meta-analysis. Environ Health Perspect. 2004;112:970-8, http://dx.doi.org/10.1289/ehp.6895.

17. Rybicki BA, Neslund-Dudas C, Bock CH, Rundle A, Savera AT, Yang JJ, et al. Polycyclic aromatic hydrocarbon - DNA adducts in prostate and biochemical recurrence after prostatectomy. Clin Cancer Res. 2008;14:750-7, http://dx.doi. org/10.1158/1078-0432.CCR-07-0986.

18. Dejmek J, Solanský I, Benes I, Lenícek J, Šrám RJ. The impact of polycyclic aromatic hydrocarbons and fine particles on pregnancy outcome. Environ Health Perspect. 2000;108(12):1159-64.

19. Perera FP, Rauh V, Whyatt RM, Tang D, Tsai WY, Bernert JT, et al. A summary of recent findings on birth outcomes and developmental effects of prenatal ETS, PAH, and pesticide exposures. Neurotoxicology. 2005;26(4):573-87, http://dx.doi.org/10.1016/j.neuro.2004.07.007.

20. Choi H, Jedrychowski W, Spengler J, Camann DE, Whyatt RM, Rauh V, et al. International studies of prenatal exposure to polycyclic aromatic hydrocarbons and fetal growth. Environ Health Perspect. 2006;114:1744-50, http:// dx.doi.org/10.1289/ehp.8982. 
21. Tang D, Li T, Liu JJ, Chen Y, Qu L, Perera F. PAH-DNA adducts in cord blood and fetal and child development in a Chinese cohort. Environ Health Perspect. 2006;114(8):1297300, http://dx.doi.org/10.1289/ehp.8939.

22. Al-Saleh I, Alsabbahen A, Shinwari N, Billedo G, Mashhour A, Al-Sarraj Y, et al. Polycyclic aromatic hydrocarbons (PAHs) as determinants of various anthropometric measures of birth outcome. Sci Total Environ. 2013;444:565-78, http://dx.doi.org/10.1016/j.scitotenv.2012.12.021.

23. Jeng HA, Yu L. Alteration of sperm quality and hormone levels by polycyclic aromatic hydrocarbons on airborne particulate particles. J Environ Sci Health A Tox Hazard Subst Environ Eng. 2008;43:675-81, http://dx.doi. org/10.1080/10934520801959815.

24. Seleven SG, Borkovec L, Slott VL, Zudova Z, Rubes J, Evenson DP. Semen quality and reproductive health of young Czech men exposed to seasonal air pollution. Environ Health Perspect. 2000;108:887-94.

25. Gaspari L, Chang SS, Santella RM, Garte S, Pedotti P, Taioli E. Polycyclic aromatic hydrocarbon-DNA adducts in human sperm as a marker of DNA damage and infertility. Mutat Res. 2003; 535:155-60, http://dx.doi.org/10.1016/ S1383-5718(02)00297-8.

26. Xia Y, Zhu P, Han Y, Lu C, Wang S, Gu A, et al. Urinary metabolites of polycyclic aromatic hydrocarbons in relation to idiopathic male infertility. Hum Reprod. 2009; 24(5):106774, http://dx.doi.org/10.1093/humrep/dep006.

27. Xia Y, Han Y, Zhu P, Wang S, Gu A, Wang L, et al. Relation between Urinary Metabolites of Polycyclic Aromatic Hydrocarbons and Human Semen Quality. Environ Sci Technol. 2009;43(12):4567-73, http://dx.doi.org/10.1021/es9000642.

28. Hsu PC, Chen IY, Pan CH, Wu KY, Pan MH, Chen JR, et al. Sperm DNA damage correlates with polycyclic aromatic hydrocarbons biomarker in coke-oven workers. Int Arch Occup Environ Health. 2006;79:349-56, http://dx.doi. org/10.1007/s00420-005-0066-3.

29. World Health Organization. WHO Laboratory Manual for the Examination of Human Semen and Sperm-Cervical
Mucus Interaction. 4th ed. Cambridge: Cambridge University Press; 1999.

30. Kruger TF, Acosta AA, Simmons KF, Swanson RJ, Matta JF, Oehninger S. Predictive value of abnormal sperm morphology in in vitro fertilization. Fertil Steril. 1988;49:112-7.

31. Vazquez-Levin MH, Goldberg SI, Friedmann P, Des Jarlais DC, Nagler HM. Papanicolaou and Kruger assessment of sperm morphology: thresholds and agreement. Int J Androl. 1998;21(6):327-31.

32. ASRM Practice Committee. Report on optimal evaluation of the infertile male. Fertil Steril. 2006;86(4):202-9, http:// dx.doi.org/10.1016/j.fertnstert.2006.08.029.

33. Jongeneelen FJ, Anzion RB, Henderson P. Determination of hydroxylated metabolites of polycyclic aromatic hydrocarbons in urine. J Chromatogr. 1987;413:227-32.

34. Polańska K, Hanke W, Sobala W, Brzeźnicki S, Ligocka D. Predictors of environmental exposure to polycyclic aromatic hydrocarbons among pregnant women - prospective cohort study in Poland. Int J Occup Med Environ Health. 2011;24(1):8-17, http://doi.dox.org/10.2478/s13382011-0003-5.

35. Koller M, Stahel WA. Sharpening Wald-type inference in robust regression for small samples. Comput Stat Data Anal. 2011;55(8):2504-15, http://dx.doi.org/10.1016/ j.csda.2011.02.014.

36. R Core Team: A language and environment for statistical computing. Vienna: R Foundation for Statistical Computing; 2012 [cited 2013 Jan 21]. Available from: http://www. R-project.org.

37. Rousseeuw P, Croux C, Todorov V, Ruckstuhl A, SalibianBarrera M, Verbeke T, et al. Package 'robustbase': Basic Robust Statistics. R package version 0.9-4, 2012 [cited 2013 Jan 21]. Available from URL: http://CRAN.R-project.org/ package $=$ robustbase .

38. Rubes J, Selevan SG, Evenson DP, Zudova D, Vozdova M, Perreault SD, et al. Episodic air pollution is associated with increased DNA fragmentation in human sperm without 
other changes in semen quality. Hum Reprod. 2005;20:277683, http://dx.doi.org/10.1093/humrep/dei122.

39. Jeng HA, Pan CH, Chao MR. 1-Hydroxypyrene as a biomarker for assessing the effects of exposure to polycyclic aromatic hydrocarbons on semen quality and sperm DNA integrity. J Environ Sci Health A Tox Hazard Subst Environ Eng. 2013;48(2):152-8, http://dx.doi.org/10.1080/03601234.2 012.716741 .

40. Jeng HA, Pan CH, Lin WY, Wu MT, Taylor S, ChangChien GP, et al. Biomonitoring of polycyclic aromatic hydrocarbons from coke oven emissions and reproductive toxicity in nonsmoking workers. J Hazard Mater. 2013;244-5:43643, http://dx.doi.org/10.1016/j.jhazmat.2012.11.008.

41. Sram RJ, Benes I, Binkova B, Rössner P, Rubes J, Topin$\mathrm{ka} J$, et al. Adverse reproductive outcomes from exposure to environmental mutagens. Mutat Res. 1999;428:203-1, http:// dx.doi.org/10.1016/S1383-5742(99)00048-4.

42. Keimig SD, Kirby KW, Morgan DP, Keiser JE, Hubert TD. Identification of 1-hydroxypyrene as a major metabolite of pyrene in pig urine. Xenobiotica. 1983;13:415-20.

43. Jacob J, Seidel A. Biomonitoring of polycyclic aromatic hydrocarbons in human urine. J Chromatogr B Analyt Technol Biomed Life Sci. 2002;778(1-2):31-47, http://dx.doi. org/10.1016/S0378-4347(01)00467-4.

44. Jongeneelen FJ. Benchmark guideline for urinary 1-hydroxypyrene as biomarker of occupational exposure to polycyclic aromatic hydrocarbons. Ann Occup Hyg. 2001;45(1): 3-13, http://dx.doi.org/10.1093/annhyg/45.1.3.

45. Izawa H, Kohara M, Watanabe G, Taya K, Sagai M. Diesel exhaust particle toxicity on spermatogenesis in the mouse is aryl hydrocarbon receptor dependent. J Reprod Dev. 2007;53:1069-78, http://dx.doi.org/10.1262/ jrd.19025.

46. Izawa H, Kohara M, Watanabe G, Taya K, Sagai M. Effects of diesel exhaust particles on the male reproductive system in strains of mice with different aryl hydrocarbon receptor responsiveness. J Reprod Dev. 2007;53:1191-7, http://dx.doi. org/10.1262/jrd.19114.

47. Schulz C, Wilhelm M, Heudorf U, Kolossa-Gehring M. Reprint of "Update of the reference and HBM values derived by the German Human Biomonitoring Commission". Int J Hyg Environ Health. 2012;215(2):150-8, http://dx.doi. org/10.1016/j.jheh.2012.01.003.

48. Kizu R, Okamura K, Toriba A, Kakishima H, Mizokami A, Burnstein KL, et al. A role of aryl hydrocarbon receptor in the antiandrogenic effects of polycyclic aromatic hydrocarbons in LNCaP human prostate carcinoma cells. Arch Toxicol. 2003;77:335-43.

49. Van de Wiele T, Vanhaecke L, Boeckaert C, Peru K, Headley J, Verstraete W, et al. Human colon microbiota transform polycyclic aromatic hydrocarbons to estrogenic metabolites. Environ Health Perspect. 2005;113:6-10, http://dx.doi. org/10.1289/ehp.7259.

50. Nebert DW, Dalton TP, Okey AB, Gonzalez FJ. Role of aryl hydrocarbon receptor-mediated induction of the CYP1 enzymes in environmental toxicity and cancer. J Biol Chem. 2004;279: 23847-50, http://dx.doi.org/10.1074/jbc.R400004200.

51. Khorram O, Garthwaite M, Jones J, Golos T. Expression of aryl hydrocarbon receptor (AHR) and aryl hydrocarbon receptor nuclear translocator (ARNT) mRNA expression in human spermatozoa. Med Sci Monit. 2004;10:135-8, http:/ dx.doi.org/10.1210/en.2002-220642.

52. Calogero A, Polosa R, Perdichizzi A, Guarino F, La Vignera S, Scarfia A, et al. Cigarette smoke extract immobilizes human spermatozoa and induces sperm apoptosis. Reprod Biomed Online. 2009;19:564-71.

53. Meeker JD, Barr DB, Hauser R. Human semen quality and sperm DNA damage in relation to urinary metabolites of pyrethroid insecticides. Hum Reprod. 2008;23:1932-40, http:// dx.doi.org/10.1093/humrep/den242.

This work is available in Open Access model and licensed under a Creative Commons Attribution-NonCommercial 3.0 Poland License - http://creativecommons.org/ licenses/by-nc/3.0/pl/deed.en. 